\title{
Do the weather parameters have influences on the proliferation of Covid-19? An analysis based on metrological reports of geographically different eight regions over the globe.
}

\author{
Md. Tarikul Islam ${ }^{1}$, Mohebul Ahsan ${ }^{1}$, and Mohammad Hasnat ${ }^{1}$ \\ ${ }^{1}$ Shahjalal University of Science and Technology
}

June 2, 2020

\begin{abstract}
A contagious disease caused by severe acute respiratory syndrome coronavirus 2 (SARS-CoV-2) is known as Coronavirus disease 2019 (Covid-19). It engendered the whole civilization within a couple of months over the globe since it was first detected in Wuhan, China in late December 2019. Variation of proliferation rates in different regions assume that climatic parameters might have a vital role in Covid-19 transmission. In this study, the correlation between Covid-19 proliferation with demographic parameter (population density), and weather parameters (temperature, humidity, precipitation, wind speed, and sunshine hour) were investigated separately within the first 60 days of Covid-19 cases. To obtain a precedent correlation, weather and infection-related data of eight different geographically coordinated regions such as Alberta (Canada), Barcelona (Spain), Dhaka (Bangladesh), Île-de-France (France), Lombardy (Italy), New York (USA), Rio de Janeiro (Brazil) and West Bengal (India) having the diversity of climates were considered. It was observed that less densely populated regions (New York, Lombardy, Barcelona) were even highly affected than the highly populated regions like Bangladesh, West Bengal. A negative correlation between total cases and temperature perhaps made this difference. The higher the wind speed perhaps accountable for long-distance viral transmission. The non-steady humidity tentatively makes the people vulnerable towards Covid-19 infections. Higher precipitation may positively affect viral infection. Sunshine along with the higher temperatures are suspected to impede the contagion by Covid-19. Consequently, peoples in the regions of lower temperatures, higher wind speed, and unstable humidity have higher risks of Covid-19 infection.
\end{abstract}

\begin{abstract}
A contagious disease caused by severe acute respiratory syndrome coronavirus 2 (SARS-CoV-2) is known as Coronavirus disease 2019 (Covid-19). It engendered the whole civilization within a couple of months over the globe since it was first detected in Wuhan, China in late December 2019. Variation of proliferation rates in different regions assume that climatic parameters might have a vital role in Covid-19 transmission. In this study, the correlation between Covid-19 proliferation with demographic parameter (population density), and weather parameters (temperature, humidity, precipitation, wind speed, and sunshine hour) were investigated separately within the first 60 days of Covid-19 cases. To obtain a precedent correlation, weather and infection-related data of eight different geographically coordinated regions such as Alberta (Canada), Barcelona (Spain), Dhaka (Bangladesh), Île-de-France (France), Lombardy (Italy), New York (USA), Rio de Janeiro (Brazil) and West Bengal (India) having the diversity of climates were considered. It was observed that less densely populated regions (New York, Lombardy, Barcelona) were even highly affected than the highly populated regions like Bangladesh, West Bengal. A negative correlation between total cases and temperature perhaps made this difference. The higher wind speed perhaps accountable for long distance viral transmission. The non-steady humidity tentatively makes the people vulnerable towards Covid-19 infections. Higher precipitation may positively affect viral infection. Sunshine along with the higher temperatures are
\end{abstract}


suspected to impede the contagion by Covid-19. Consequently, peoples in the regions of lower temperatures, higher wind speed, and unstable humidity have higher risks of Covid-19 infection.

Keywords: Covid-19; population; viral proliferation; weather parameters; contagion.

\section{Introduction}

Covid-19 is one of the most uttered word since the outbreak of a contagious disease proliferated from the virus called SARS-CoV-2 in late December 2019. It was first detected at Wuhan in the Hubei province of China in December $2019^{1}{ }^{23}$. The Covid-19 has been regarded as history broken contagious disease as no other viral disease proliferated across the globe in the history at the same time. Despite taking immediate cautions to stop proliferation of this virus, it has travelled almost all over the globe through human to human interactions and engendered a pandemic situation threatening the healthcare systems of many countries. This virus is proved to be a highly contagious and proliferated more rapidly compared to any the other viruses of the Corona virus family ${ }^{4}$. Scientists around the world believe that this virus is spreading from the droplets thrown by coughing or sneezing by the infected individuals. These droplets may survive in air and in different types of surfaces for several hours and can potentially affect even healthy peoples come in contact ${ }^{5}$. However, the survival of these viral droplets may depend on some weather parameters like; temperature, humidity, and wind speed and of combined effects ${ }^{6}{ }^{8}$. At high temperature, the viral proliferation may significantly be impeded as it deactivates the pathogen by decomposing the protecting protein layer ${ }^{9}$. Humidity can also be an integrated factor with wind speed as the droplets may survive extensive amount of time in dry, cold air and along with high speed wind that will cause faster transmission comparing to no humid areas ${ }^{10}$.

Meanwhile, the human immune system can play an intricate role during the spreading of such contagious diseases. Some infected individuals may not have explicit symptoms, whereas others may face serious health conditions. Basically, immune response depends on how quickly human body can prepare its biological defenders for viral attack. These responses may be influenced by a bunch of factors specially the availability of vitamins $\mathrm{C}$ and $\mathrm{D}$ in our body. However, we all aware of the fact that the source of vitamin $\mathrm{D}$ is mainly sunlight where in presence of photons, the cholesterol underneath our skin converted into cholecalciferol or vitamin $\mathrm{D}^{11}$. Note that the average sunshine hour within any infected region can largely affect the immune response developed against infectious diseases ${ }^{12}$. In case of Covid-19, it can remain incubated inside human

body up to 14 days $^{13}$. During this incubation period, active immune response may suppress the replication of this virus and substantially leading to no visible symptoms and these cases are not likely to appear into the total number of cases identified ${ }^{14}$.

However, since Covid-19 is a global issue and is a threat for whole human being, thus in the present research work, we attempted to unveil the relation between Covid-19 proliferation and various climatic parameters based on metrological data obtained from different zones over the globe as shown in global map in Fig.1 . For analysis, the geographically different eight locations such as Alberta (Canada), New York (USA), Rio de Janeiro (Brazil), Barcelona (Spain), Île-de-France (France), Lombardy (Italy), West Bengal (India), and Dhaka (Bangladesh) were selected based on the diversity of weather, Covid-19 cases and population. In this study, we considered first 60 days of Covid-19 proliferation since most of the local authorities paid their best efforts to sluggish/stop the proliferation within this period. 


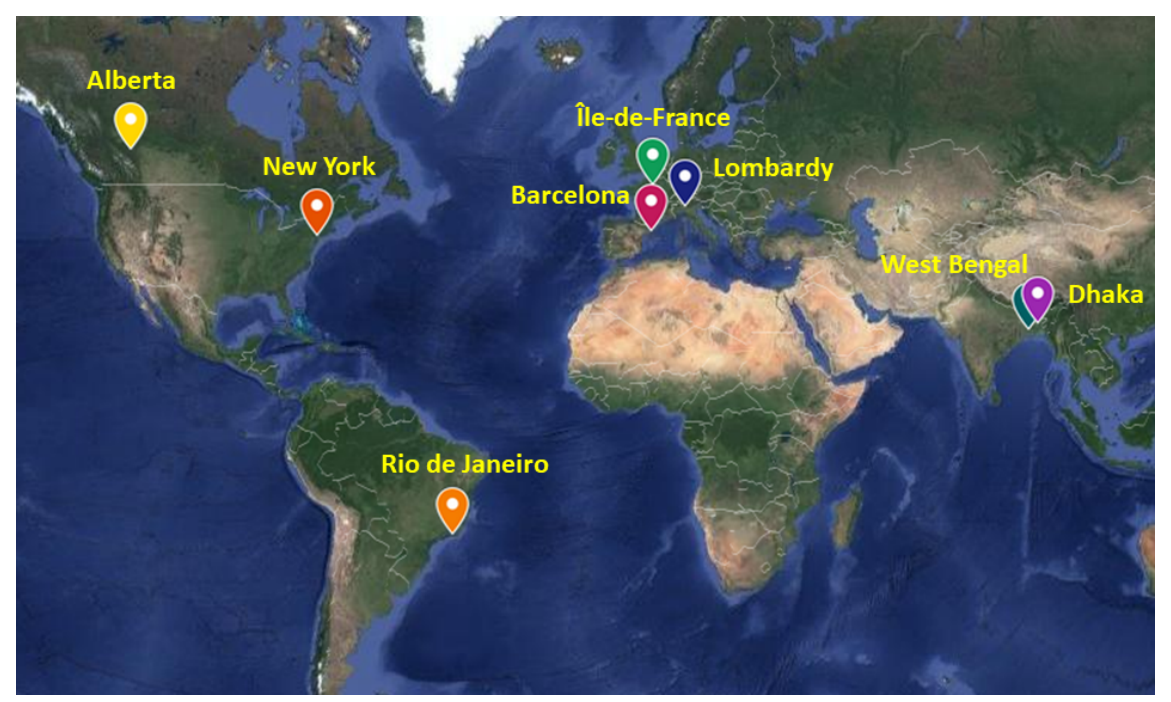

Fig. 1. Global map and the locations of the study areas.

\section{Methodology}

Several meteorological data such as temperature, humidity, wind speed, total precipitations and average sunshine hour of March to mid-May, 2020 were gleaned from different authentic web sources such as (https://www.accuweather.com/), (https://www.timeanddate.com/) and (https://www.meteoblue.com/). We collected Covid-19 cases for first 60 days of proliferation of geographically different eight locations such as Alberta (Canada), New York (USA), Rio de Janeiro (Brazil), Barcelona (Spain), Île-de-France (France), Lombardy (Italy), West Bengal (India), and Dhaka (Bangladesh) from trusted sources [(https://www.bing.com/covid/), (https://www.gouvernement.fr/info-coronavirus), (https://www1.nyc.gov/site/doh/covid), and (https://www.catalannews.com/)]. We selected these locations (shown in global map in Fig. 1) as of having diversity of weather during the Covid-19 proliferation and the people of the cited areas faced serious viral infections. Unlike previous specific geographical cases, we explained the nexus between Covid-19 cases with different kinds of weather parameters. As social distance and quarantine can reduce contact rates in a notable manner, hence, population density has direct effect on spreading Covid-19 infection. To inspect these phenomena, we collected population density data from (https://worldpopulationreview.com) to assume how people in these regions can maintain minimum distance if they stay homogenously so that they can follow social distancing manners properly. A correlation between temperature, humidity, wind speed, precipitation, sunshine hour and day by day identified infected cases of Covid-19 within 15 days interval was calculated by applying Spearman's rank correlation formula ${ }^{15}$.

\subsection{Results and discussion}

\subsection{Population density and Covid-19 cases}

Table 1 represents geographical coordinates and demographic information of the regions under study. As Covid-19 is a highly contagious disease, the rate of proliferation may depend on the rate of contact between the infected individuals in different places across the globe. It is analogous to the collision between particles in any confined system, which means that higher the number of particles, higher will be the collision frequency. From this viewpoint, we considered different geographical regions those have diversity in climate parameters (such as temperature, humidity, wind speed, sunshine hour, and total precipitation), population densities and urban structures.

Table 1. Cordinates and demographic data of of the study areas ${ }^{a}$ 


\begin{tabular}{|c|c|c|c|c|c|}
\hline Region & Coordinates & $\begin{array}{l}\text { Population } \\
\text { (Millions) }\end{array}$ & $\operatorname{Area}\left(\mathrm{km}^{2}\right)$ & $\operatorname{MDI}^{\mathrm{b}}(\mathbf{m})$ & $\begin{array}{l}\text { Period of } \\
\text { studies }(2020)\end{array}$ \\
\hline $\begin{array}{l}\text { Alberta } \\
\text { (Canada) }\end{array}$ & $\begin{array}{l}53.9333^{\circ} \mathrm{N}, \\
116.5765^{\circ} \mathrm{W}\end{array}$ & 4.37 & 661848 & 408 & $\begin{array}{l}8^{\text {th }} \text { Mar }-7^{\text {th }} \\
\text { May }\end{array}$ \\
\hline $\begin{array}{l}\text { Barcelona } \\
\text { (Spain) }\end{array}$ & $\begin{array}{l}41.3851^{\circ} \mathrm{N}, \\
2.1734^{\circ} \mathrm{E}\end{array}$ & 5.75 & 101.9 & 4.24 & $\begin{array}{l}1^{\text {st }} \text { Mar }-30^{\text {th }} \\
\text { Apr }\end{array}$ \\
\hline $\begin{array}{l}\text { Dhaka } \\
\text { (Bangladesh) }\end{array}$ & $\begin{array}{l}23.8103^{\circ} \mathrm{N} \\
90.4125^{\circ} \mathrm{E}\end{array}$ & 21.05 & 306.4 & 3.81 & $\begin{array}{l}8^{\text {th }} \text { Mar }-7^{\text {th }} \\
\text { May }\end{array}$ \\
\hline $\begin{array}{l}\text { Île-de-France } \\
\text { (France) }\end{array}$ & $\begin{array}{l}48.8499^{\circ} \mathrm{N}, \\
2.6370^{\circ} \mathrm{E}\end{array}$ & 12.21 & 12012 & 31.35 & $\begin{array}{l}10^{\text {th }} \text { Mar }-9^{\text {th }} \\
\text { May }\end{array}$ \\
\hline $\begin{array}{l}\text { Lombardy } \\
\text { (Italy) }\end{array}$ & $\begin{array}{l}45.4791^{\circ} \mathrm{N}, \\
9.8452^{\circ} \mathrm{E}\end{array}$ & 10.06 & 23844 & 48.68 & $\begin{array}{l}2^{\text {nd }} \text { Feb }-19^{\text {th }} \\
\text { Apr }\end{array}$ \\
\hline $\begin{array}{l}\text { New York } \\
\text { (USA) }\end{array}$ & $\begin{array}{l}40.7128^{\circ} \mathrm{N} \\
74.0060^{\circ} \mathrm{W}\end{array}$ & 19.44 & 783.8 & 9.70 & $\begin{array}{l}1^{\text {st }} \text { Mar }-30^{\text {th }} \\
\text { Apr }\end{array}$ \\
\hline $\begin{array}{l}\text { Rio de Janeiro } \\
\text { (Brazil) }\end{array}$ & $\begin{array}{l}22.9068^{\circ} \mathrm{S} \\
43.1729^{\circ} \mathrm{W}\end{array}$ & 13.46 & 1255 & 9.50 & $\begin{array}{l}6^{\text {th }} \text { Mar }-5^{\text {th }} \\
\text { May }\end{array}$ \\
\hline $\begin{array}{l}\text { West Bengal } \\
\text { (India) }\end{array}$ & $\begin{array}{l}22.9868^{\circ} \mathrm{N} \\
87.8550^{\circ} \mathrm{E}\end{array}$ & 91.34 & 88752 & 3.11 & $\begin{array}{l}20^{\text {th }} \text { Mar- } 19^{\text {th }} \\
\text { May }\end{array}$ \\
\hline
\end{tabular}

${ }^{a}$ Source:[ https://www.gps-coordinates.net/ ], [https://worldpopulationreview.com]

${ }^{b} \mathrm{MDI}=$ (Theoretical Minimum Distance of Interaction)

Considering the total number of people live in these regions, West Bengal, Dhaka, and Barcelona own the most density than rest of the others and minimum theoretical distance of Interaction (MDI) can be maintained almost within 3.0 to $4.5 \mathrm{~m}$ between two individuals in hypothetical homogenous condition. This MDI is seemingly enough for the cited regions to keep themselves isolated according to the instruction of World Health Organization (WHO) which is at least $3.0 \mathrm{~m}$ to reduce the risk of transmission among individuals ${ }^{16}$. But in real life scenario, it is almost impossible to maintain such homogenous interpersonal distance. In fact, people have general tendency to interact with each other making it extremely difficult to maintain minimum distance particularly in Dhaka and West Bengal, whereas people in Alberta, île-deFrance, Lombardy and even in New York may maintain large extent of interpersonal distances. However, in conjunction to the total number of Covid-19 cases identified in New York, Lombardy and Île-de-France, Dhaka and West Bengal encountered a limited number of cases in the first 60 days from the very first day of infection as shown in Figure 2 . It can be seen from this Figure that Covid-19 cases increased alarmingly around after 15 days of first Covid-19 detection and Covid-19 case vs. time curves resemble to an exponential factor. Based on average proliferation rate, the study areas could be arranged with an decreasing order; New York $(\mathbf{3 1 2 5}$ day $\left.^{1}\right)>$ Lombardy $\left(\mathbf{1 7 2 0}\right.$ day $\left.^{-1}\right)>$ Barcelona $\left(\mathbf{1 3 7 5}^{-1}\right.$ day $\left.^{-1}\right)>$ Ile-de-France $\left(\mathbf{5 6 0 \text { day } ^ { - 1 }}\right)>$ Dhaka $\left(\mathbf{4 1 8 \text { day } ^ { - 1 }}\right)$ $>$ Rio de Janeiro $\left(\mathbf{1 4 0 \text { day } ^ { - 1 } )}>\right.$ Alberta $\left(\mathbf{6 4}\right.$ day $\left.^{-1}\right)>$ West Bengal $\left(\mathbf{4 4}\right.$ day $\left.^{-1}\right)$. This order of proliferation is incongruous with the population density argument. Hence, the basis of discussion is impertinent in terms of calculating minimum distance of interpersonal interactions. This means that there must have some other factors beyond population density related to such catastrophic surge of Covid-19 cases across the globe. To resolve this incongruity, the influences of weather parameters such as temperature, humidity, wind speed, and sunshine might have influences on the rate of Covid-19 proliferation across the globe. In this conjunction, we analyzed the impacts of weather parameters on the total number of Covid-19 cases. 


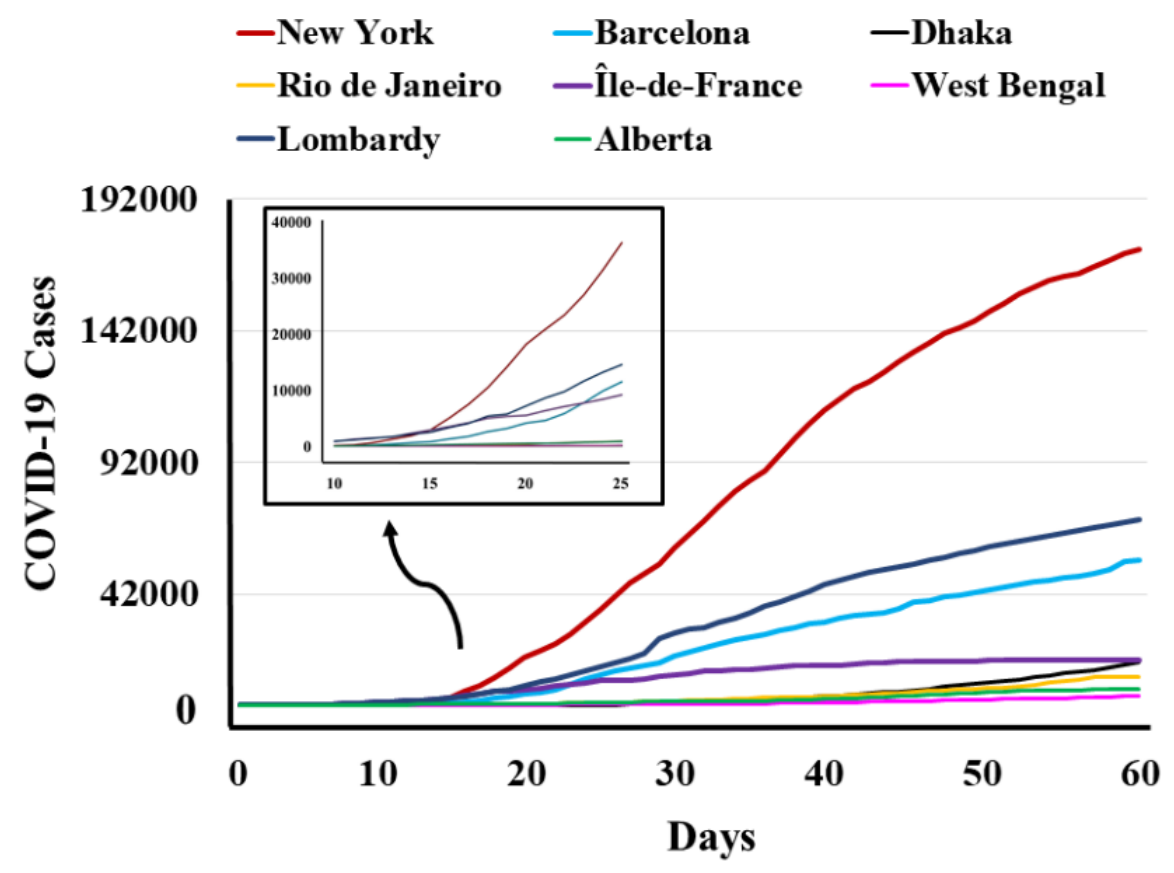

Fig. 2. Proliferation of Covid-19 cases in the study areas within the first 60 days. The inset shows the expanded view of Covid-19 cases between 10 and 25 days.

\subsection{Analysis of weather parameters}

The most influential factors may be the total weather conditions and related parameters such as temperature, humidity, total rainfall, wind speed, and sunshine. The average temperature and sunshine hour variation within the study regions were compared to each other along with other crucial environmental parameters those proved to have an intricate influence on spreading of the virus. 


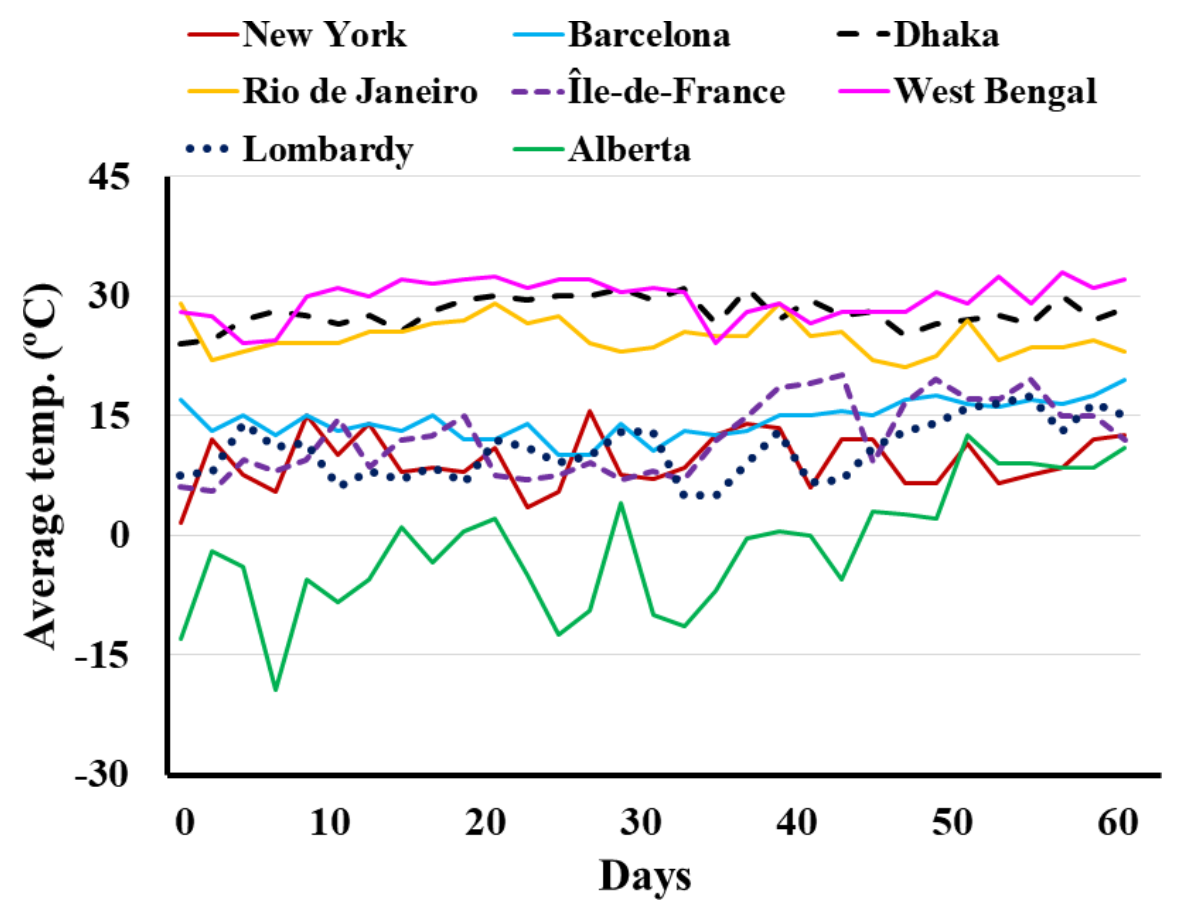

Fig. 3. Variation of average temperature in the study areas for first 60 days of Covid-19 proliferation.

Figure 3 shows that within first 60 days of first detection, the average temperature of less affected regions such as Dhaka, West Bengal and Rio de Janeiro was comparatively higher than that of New York, Barcelona, Île-de-France, and Lombardy. This observation clearly infers that the diversity of temperature must have a momentous influence on Covid-19 transmission. Although temperature can play as an integral part of curbing Covid-19 transmission, it is not the sole determining parameter where other parameters such as humidity, wind speed, sunshine, precipitation may also have potential impact on this unprecedented situation. 


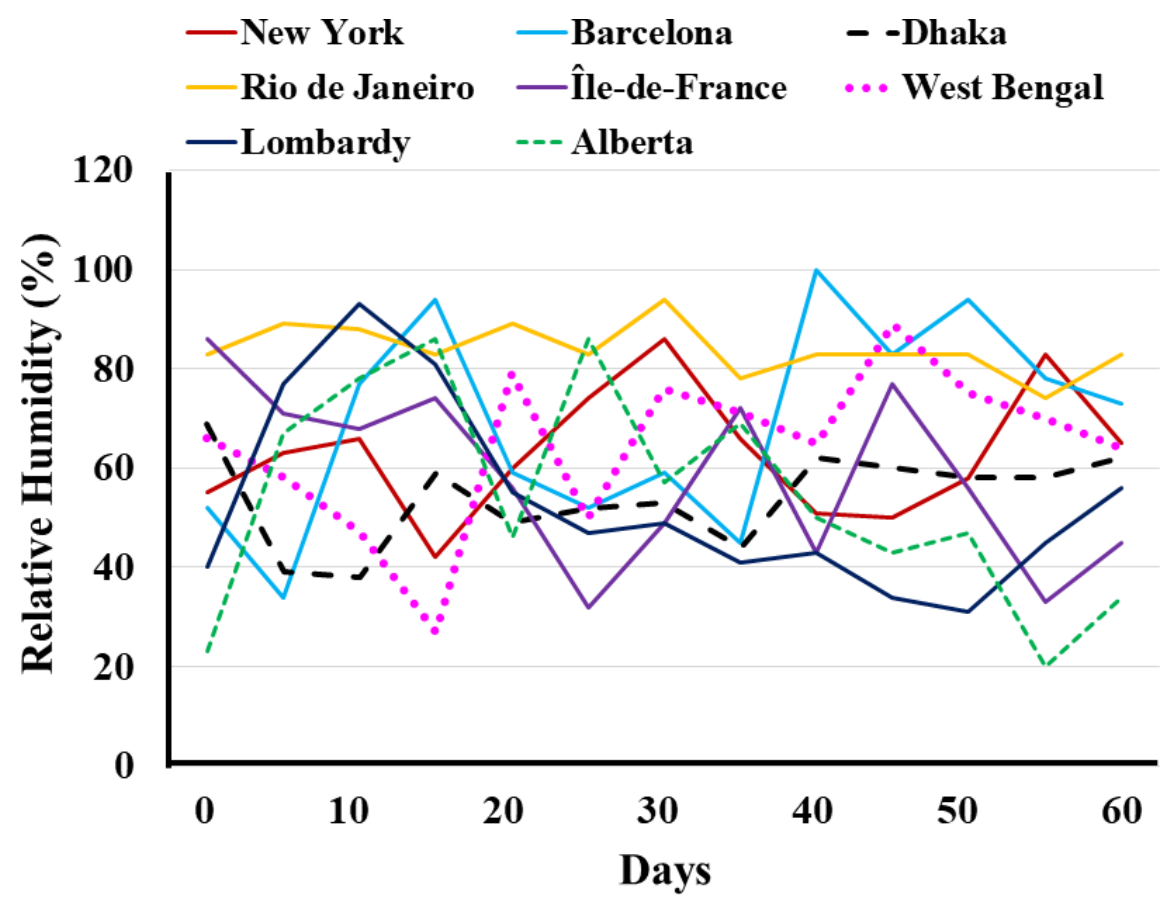

Fig 4. Variation of relative humidity in the study areas for first 60 days of Covid -19 proliferation.

Figure 4 shows the variation of humidity within first 60 days of Covid-19 proliferation across the study areas. The relative humidity variation for the first 60 days was observed stable for Dhaka and Rio de Janeiro whereas, huge fluctuation is explicit for other regions with relatively low temperatures. Apparently, lower temperature along with humidity imbalance have acute effect on respiration process ultimately driving people more vulnerable state to be affected by SARS-CoV-2 Virus. 


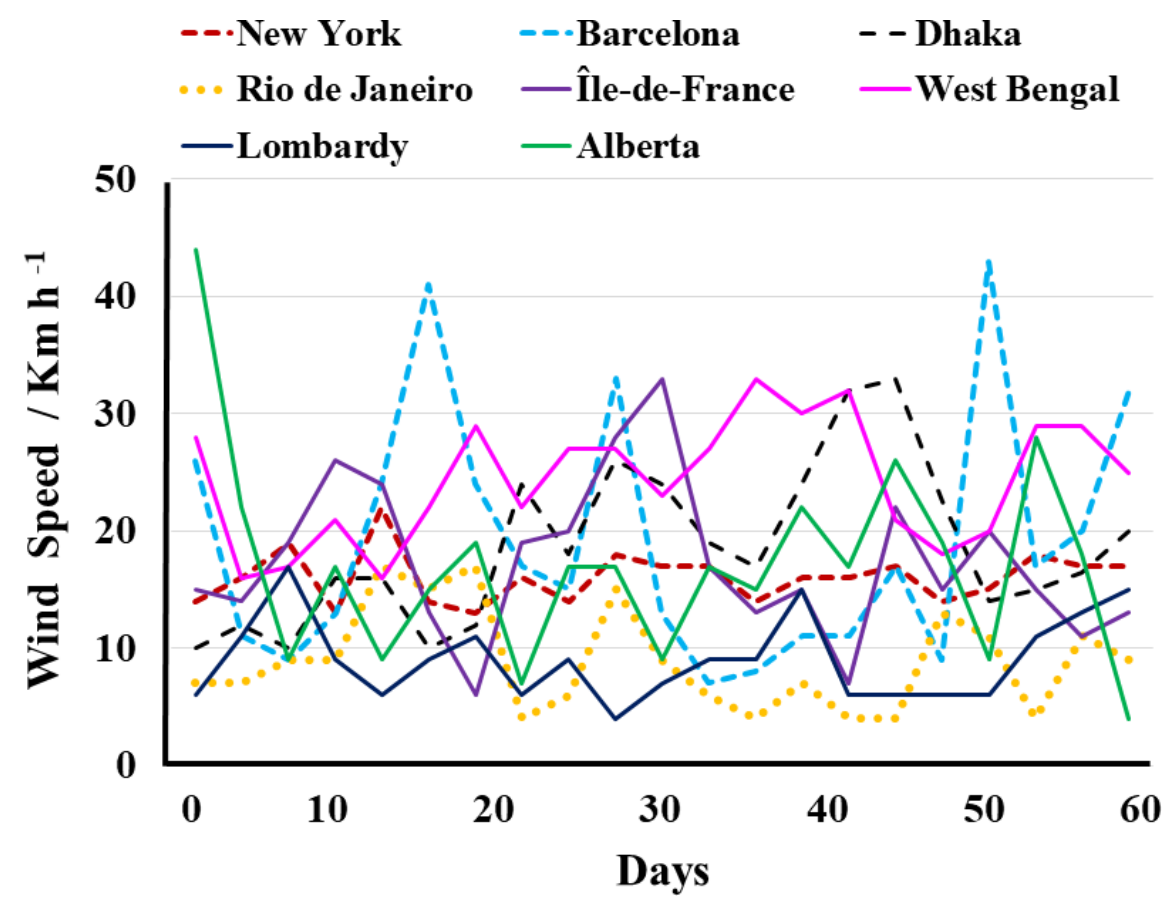

Fig 5. Variation of wind speed in the study areas for first 60 days of Covid-19 proliferation.

Meanwhile, considering the wind speed shown in Figure 5, in the affected regions, Barcelona shows frequent spikes with high speed of wind per kilometre. On stark contrast, Rio di Janeiro remained under low average air movement in its atmosphere, which may be attributed to the lower number of cases detected in referred time length. It is thus probable that high wind speed combined with unsteady humidity might cause augmentation in number of cases.

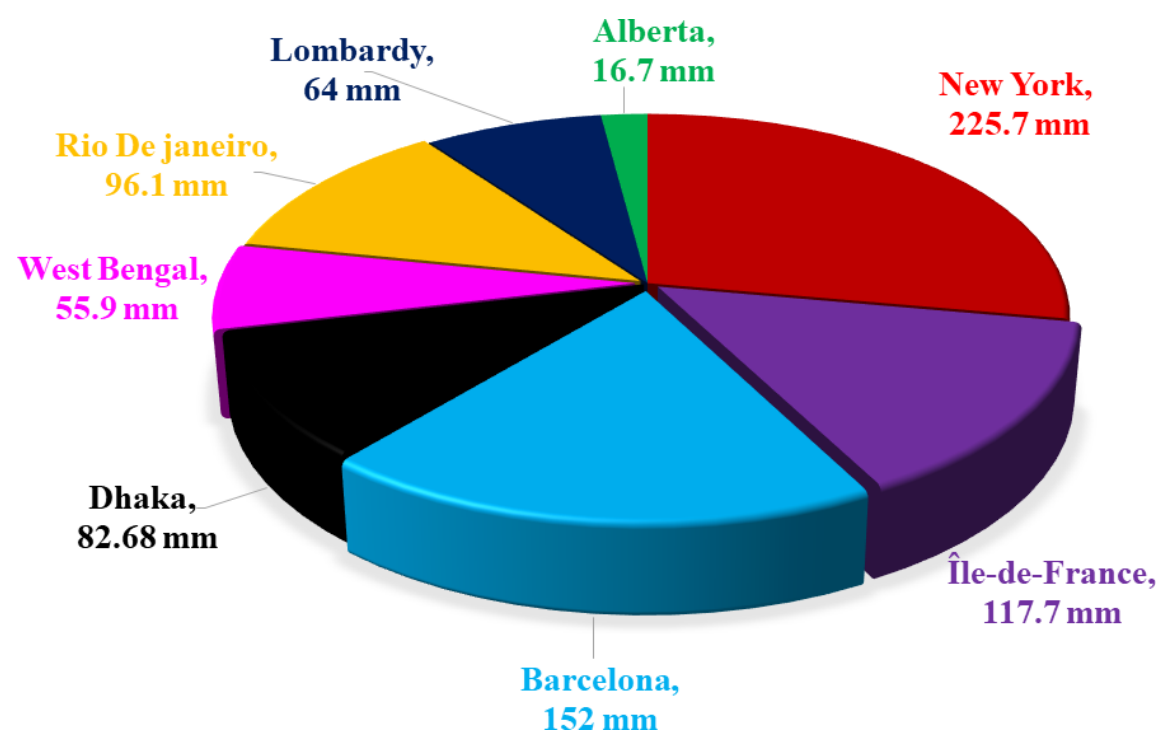

Fig. 6. Pie chart of total precipitation in the study areas within first 60 days of Covid-19 proliferation. 
Next, we attempted to document total precipitation data for first 60 days regarding eight regions in different parts of the globe. From the visualization of Fig. $\mathbf{6}$, it is confirmed that the total precipitation is another key factor in parallel with temperature considering the total number of Covid-19 cases in regions (with average lower temperatures) such as New York, Barcelona, and Île-de-France. On quite contrary, other regions with average lower amount of precipitation counts relatively insignificant amount of cases.

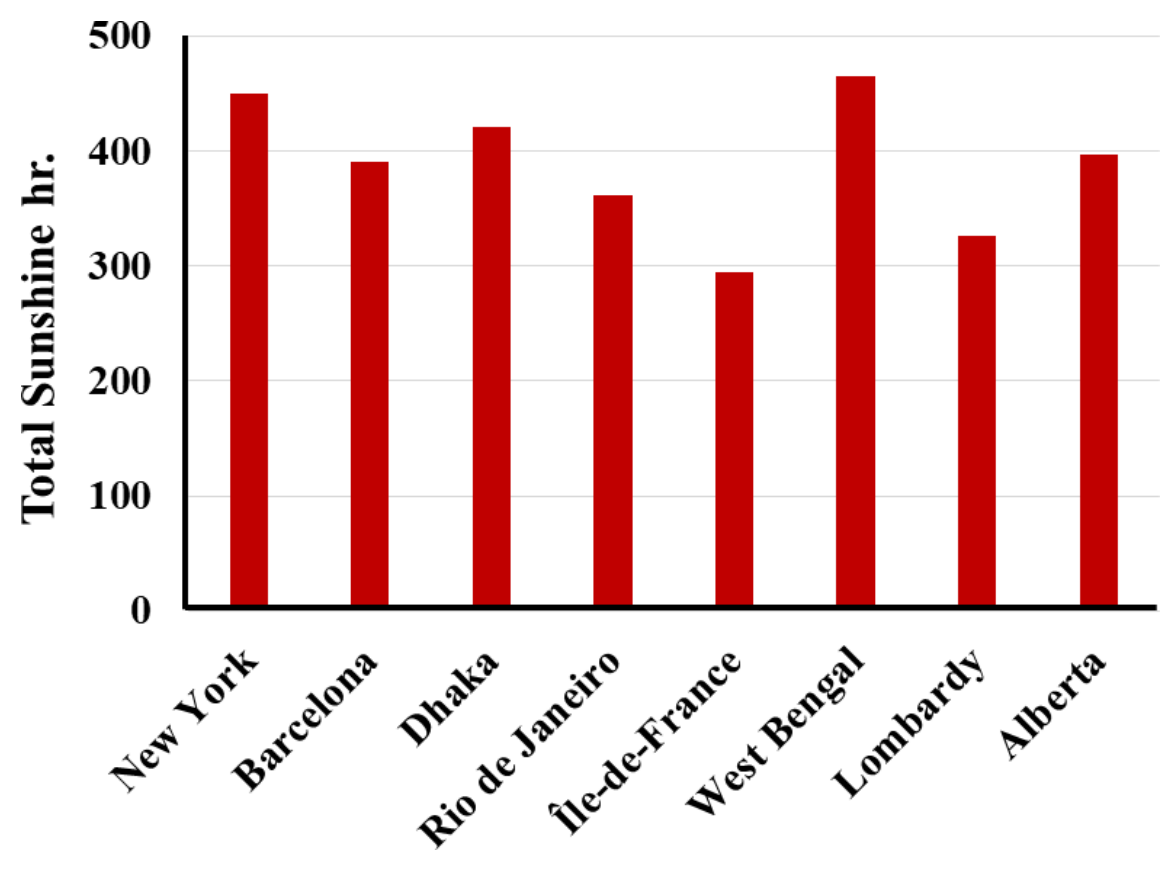

Fig. 7. Total sunshine hours (March and April) in the study areas within the first 60 days of Covid-19 proliferation.

Lastly, we counted the influence of sunshine hours on Covid-19 proliferation as shown in Fig. $\mathbf{7}$. It is a citing concern that average sunshine may have an impact on Covid-19 cases. The average total sunshine period may be quite an influential factor in March and April considering the number of Covid-19 cases. We already know that exposure to sunshine catalyse the conversion of cholesterol into cholecalciferol which is known as Vitamin D strengthen human immune system to fight against any infectious disease. But, at lower temperatures such catalytic conversion into vitamin D may be impeded even in presence of affluence of sunshine. Because of geographical coordinates, despite having plenty of sunshine in New York, Barcelona, Alberta, and Lombardy, the optimum condition for enzymatic conversion might not be fulfilled at relatively low temperatures comparing to Dhaka and West Bengal. Lower temperature along with relatively lower sunshine could have aggravated the situation for instance of Île-de-France and similar regions.

\subsection{Statistical Analysis}

To establish a correlation between the total number of identified cases and the weather parameters, we calculated the Spearman's rank correlation coefficients for temperature, humidity, and wind speed. The experimental recorded dataset was not ordered in nature, so it is definite to use rank correlation measurement for disclosing any relation between weather parameters and viral affected numbers. This rank correlation coefficient determines how strongly two given variables are dependent to each other. By using Eq. 1 we have calculated the Spearman's rank correlation coefficients for 60 days.

$r_{s}=1-6 \frac{\sum 2 \underline{2}}{n^{3}-n}$

Where, $d_{i}$ is the difference between ranks of two variables, ' $n$ ' is the sample size and $r_{s}$ is the spearman's 
rank correlation coefficient.

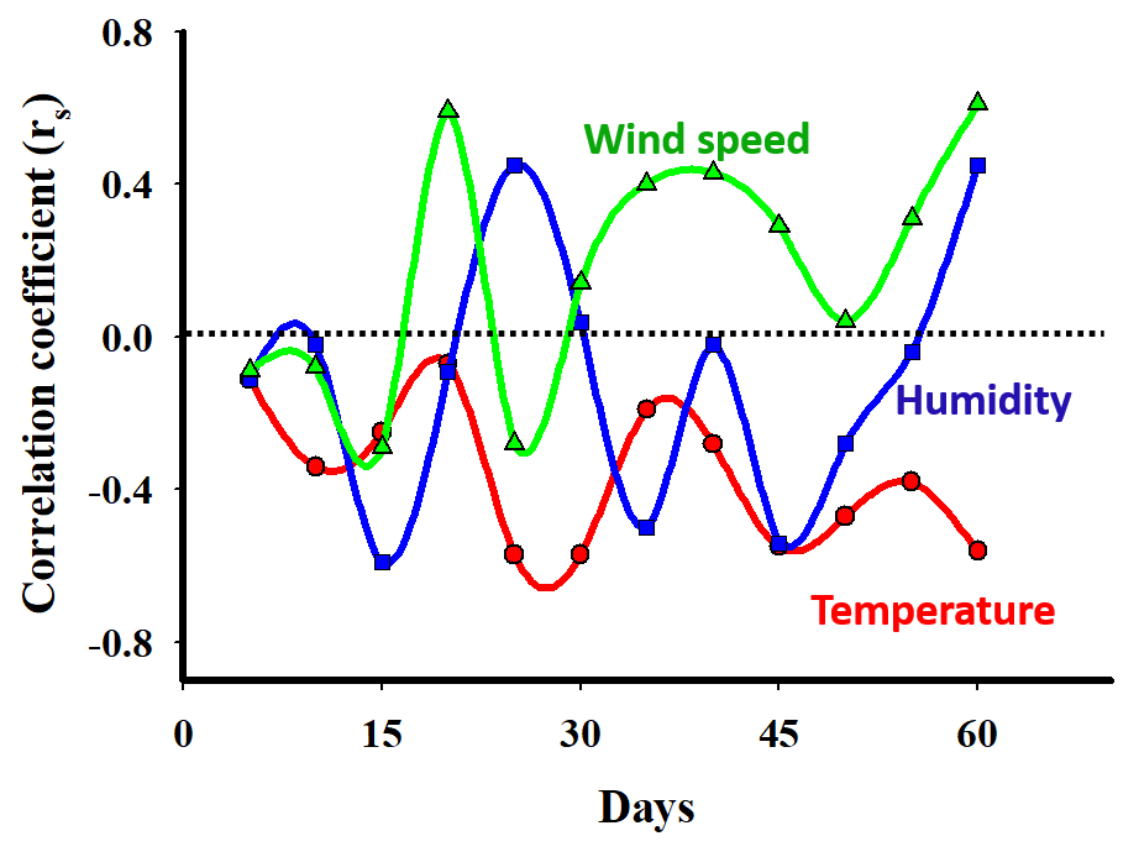

Fig. 8. Dependency of correlation coefficient $\left(r_{s}\right)$ on temperature, humidity, and wind speed.

Figure 8 shows how correlation coefficient varied with three major weather parameters within the study period. The correlation $\left(\mathrm{r}_{\mathrm{s}}\right)$ between temperature and total number of cases within five-day intervals was found to vary from -0.11 to -0.57 , which denotes a negative correlation. As it is thought that SARS-CoV-2 virus may survive for an extensive period at lower temperature, it is more likely to affect people around the regions where the temperature is relatively low ${ }^{17}$. At higher temperatures, the viral envelop, made of protein polymers, may decompose to make the viral genomic material exposed and eventually deactivated ${ }^{9}$. This means that at lower temperatures, the number of Covid-19 cases may intensify with upward spiral. From Figure 3, it is obvious that Barcelona, New York, and Île-de-France had conducive temperature to make it possible for viral transmission which perhaps happened in those cases. Wind speed is another influential parameter for virus transmission ${ }^{18}$ which has been correlated with total number of cases. Herein our findings, based on the variation of wind speed during the first 60 days of Covid-19 transmission, indicates that within most of the time, the value coefficient $\left(\mathrm{r}_{\mathrm{s}}\right)$ was found positive with a maximum value of 0.61 . This observation strengthens the idea that wind speed may play vital role regarding the spreading of airborne diseases like Covid- $19^{19}$.

Although we had not found any specific relation of humidity fromFigure $\mathbf{4}$, the correlation coefficients with total cases mostly shows negative values at an extreme of $r_{s}=-0.59$. This means that the instability of humidity could be helpful for the propagation of the virus.

Consequently, the SARS-CoV-2 is one of the viruses that may transmit through micro droplets ejected from the affected individuals by coughing and sneezing. At higher wind speeds, coughing droplets may travel to longer distances, and the technique of interpersonal distancing to avoid the virus may not work. In the case of regions like Barcelona with relatively lower average temperature, high wind speed probably exacerbated the situation whereas in warmer regions, for example, Dhaka and West Bengal, the effect of high wind speed might have supressed by the higher temperatures. Spikes of humidity may help the propagation of Covid-19 cases. 


\section{Conclusion}

Covid-19 proliferation across the globe is threatening the survival of human lives. To unveil how the proliferation Covid-19 is modulated with the physical parameters, the weather reports of eight geographically different regions across the globe were analysed for 60-day long period since first identified case. It is not surprising that the contagious virus will spread in the densely populated areas where maintaining minimum social distance is highly challenging. Nevertheless, it was observed that comparatively less populated regions such as New York, Lombardy, Île-de-France, and Barcelona etc infected more rapidly than the relatively densely populated regions like Dhaka, West Bengal, and Rio de Janeiro. The diversity of weather has been identified for this discrepancy. It has been concluded that regions with lower temperature, higher precipitation with higher wind speeds and unstable humidity is ideal for Covid-19 infections.

\section{ACKNOWLEDGMENT}

The authors thank TWAS and SIDA for a research grant (2019_19-222 RG/CHE/AS_G), for partial support of this research work. The authors also acknowledge the Ministry of Science and Technology, Bangladesh and Shahjalal University of Science and Technology for allocating partial grants.

\section{References}

1. Hua W, Xiaofeng L, Zhenqiang B, Jun R, Ban W, Liming L. Consideration on the strategies during epidemic stage changing from emergency response to continuous prevention and control. Chinese $J$ Endem . 2020;41(2):297-300. doi:10.3760/cma.j.issn.0254-6450.2020.02.003

2. Novel Coronavirus Pneumonia Emergency Response Epidemiology Team. Vital surveillances: the epidemiological characteristics of an outbreak of 2019 novel coronavirus diseases (COVID-19) - China, 2020. China CDC Wkly . 2020;2(8):113-122

3. Prevention CC for DC and. The Epidemiological Characteristics of an Outbreak of 2019 Novel Coronavirus Diseases (COVID-19) — China, 2020 The Novel Coronavirus Pneumonia Emergency Response Epidemiology Team. CCDC Wkly . 2020;2(8):5

4. Chen J. Pathogenicity and transmissibility of 2019-nCoV-A quick overview and comparison with other emerging viruses. Microbes Infect . 2020;22(2):69-71. doi:10.1016/j.micinf.2020.01.004

5. Casanova LM, Jeon S, Rutala WA, Weber DJ, Sobsey MD. Effects of air temperature and relative humidity on coronavirus survival on surfaces. Appl Environ Microbiol . 2010;76(9):2712-2717. doi:10.1128/AEM.0229109

6. Minhaz Ud-Dean SM. Structural explanation for the effect of humidity on persistence of airborne virus: Seasonality of influenza. J Theor Biol . 2010;264(3):822-829. doi:10.1016/j.jtbi.2010.03.013

7. Zhang H, Zeng Y. Transmissibility of COVID-19 and its association with temperature and humidity. Res $S q$. 2020:1-12. doi:10.21203/rs.3.rs-17715/v1

8. Mecenas P, Bastos R, Vallinoto A, Normando D. Effects of temperature and humidity on the spread of COVID-19: A systematic review.medRxiv . 2020:2020.04.14.20064923. doi:10.1101/2020.04.14.20064923

9. Kampf G, Voss A, Scheithauer S. Inactivation of coronaviruses by heat. J Hosp Infect . 2020;0(0). doi:10.1016/j.jhin.2020.03.025

10. Ahmadi M, Sharifi A, Dorosti S, Jafarzadeh Ghoushchi S, Ghanbari N. Investigation of effective climatology parameters on COVID-19 outbreak in Iran. Sci Total Environ . 2020;729:138705. doi:10.1016/j.scitotenv.2020.138705

11. Schwalfenberg GK. A review of the critical role of vitamin D in the functioning of the immune system and the clinical implications of vitamin D deficiency. Mol Nutr Food Res . 2011;55(1):96-108. doi: $10.1002 / \mathrm{mnfr} .201000174$ 
12. Cantorna MT. Mechanisms underlying the effect of vitamin D on the immune system. In: Proceedings of the Nutrition Society . Vol 69. NIH Public Access; 2010:286-289. doi:10.1017/S0029665110001722

13. Lauer SA, Grantz KH, Bi Q, et al. The incubation period of coronavirus disease 2019 (CoVID-19) from publicly reported confirmed cases: Estimation and application. Ann Intern Med . 2020;172(9):577-582. doi:10.7326/M20-0504

14. Hu Z, Song C, Xu C, et al. Clinical characteristics of 24 asymptomatic infections with COVID-19 screened among close contacts in Nanjing, China. Sci China Life Sci . 2020;63(5):706-711. doi:10.1007/s11427-020$1661-4$

15. Gauthier TD. Detecting trends using spearman's rank correlation coefficient. Environ Forensics . 2001;2(4):359-362. doi:10.1080/713848278

16. Rational use of personal protective equipment for coronavirus disease (COVID-19) and considerations during severe shortages. https://www.who.int/publications-detail/rational-use-of-personal-protectiveequipment-for-coronavirus-disease-(covid-19)-and-considerations-during-severe-shortages. Accessed June 1, 2020 .

17. Notari A. Temperature dependence of COVID-19 transmission. March 2020. http://arxiv.org/abs/2003.12417. Accessed June 1, 2020.

18. Ningthoujam R. COVID 19 can spread through breathing, talking, study estimates. Curr Med Res Pract . May 2020. doi:10.1016/j.cmrp.2020.05.003

19. Bhattacharjee S. Statistical investigation of relationship between spread of coronavirus disease (COVID19) and environmental factors based on study of four mostly affected places of China and five mostly affected places of Italy. March 2020. http://arxiv.org/abs/2003.11277. Accessed June 1, 2020. 